\title{
Can the single-breath helium dilution method predict lung volumes as measured by whole-body plethysmography?*
}

\author{
Pode o método de diluição do hélio em respiração única estimar os \\ volumes pulmonares medidos pela pletismografia de corpo inteiro?* \\ Patrícia Chaves Coertjens, Marli Maria Knorst, Anelise Dumke, \\ Adriane Schmidt Pasqualoto, João Riboldi, Sérgio Saldanha Menna Barreto
}

\begin{abstract}
Objective: To compare TLC and RV values obtained by the single-breath helium dilution (SBHD) method with those obtained by whole-body plethysmography (WBP) in patients with normal lung function, patients with obstructive lung disease (OLD), and patients with restrictive lung disease (RLD), varying in severity, and to devise equations to estimate the SBHD results. Methods: This was a retrospective cross-sectional study involving 169 individuals, of whom 93 and 49 presented with OLD and RLD, respectively, the remaining 27 having normal lung function. All patients underwent spirometry and lung volume measurement by both methods. Results: TLC and RV were higher by WBP than by SBHD. The discrepancy between the methods was more pronounced in the OLD group, correlating with the severity of airflow obstruction. In the OLD group, the correlation coefficient of the comparison between the two methods was 0.57 and 0.56 for TLC and RV, respectively $(p<0.001$ for both). We used regression equations, adjusted for the groups studied, in order to predict the WBP values of TLC and RV, using the corresponding SBHD values. It was possible to create regression equations to predict differences in TLC and RV between the two methods only for the OLD group. The TLC and RV equations were, respectively, $\Delta \mathrm{TLC}_{\text {WBP-SBHD }}$ in $\mathrm{L}=5.264-0.060 \times \mathrm{FEV}_{1} / \mathrm{FVC}\left(\mathrm{r}^{2}=0.33\right.$; adjusted $\left.\mathrm{r}^{2}=0.32\right)$ and $\Delta \mathrm{RV}_{\text {WBP-SBHD }}$ in $\mathrm{L}=$ $4.862-0.055 \times \mathrm{FEV}_{1} / \mathrm{FVC}\left(\mathrm{r}^{2}=0.31\right.$; adjusted $\left.\mathrm{r}^{2}=0.30\right)$. Conclusions: The correction of TLC and RV results obtained by SBHD can improve the accuracy of this method for assessing lung volumes in patients with OLD. However, additional studies are needed in order to validate these equations.
\end{abstract}

Keywords: Plethysmography, whole body; Total lung capacity; Residual volume.

\section{Resumo}

Objetivo: Comparar resultados de CPT e VR obtidos pelo método de diluição de hélio em respiração única (DHRU) com aqueles obtidos por pletismografia de corpo inteiro ( $\mathrm{PCl}$ ) em indivíduos com função pulmonar normal, portadores de distúrbio ventilatório obstrutivo (DVO) e portadores de distúrbio ventilatório restritivo (DVR) com diferentes níveis de gravidade e elaborar equações para estimar CPT e VR por DHRU. Métodos: Estudo transversal retrospectivo com 169 indivíduos, dos quais, respectivamente, 93, 49 e 27 apresentavam DVO, DVR e espirometria normal. Todos realizaram espirometria e determinação de volumes pulmonares pelos dois métodos. Resultados: Os valores de CPT e VR foram maiores por PCl que por DHRU. A discrepância entre os métodos foi mais acentuada no grupo com DVO e se relacionou com a gravidade da obstrução ao fluxo aéreo. No grupo com DVO, o coeficiente de correlação da comparação entre os dois métodos foi de 0,57 e 0,56 para CPT e VR, respectivamente ( $p<0,001$ para ambos). Para predizer os valores de CPT e VR por PCl utilizando os respectivos valores por DHRU foram utilizadas equações de regressão, corrigidas de acordo com os grupos estudados. Somente foi possível criar equações de regressão para predizer as diferenças de CPT e VR entre os dois métodos para pacientes com DVO. Essas equações foram, respectivamente, $\Delta \mathrm{CPT}_{\text {PCI-DHRU }}$ em $\mathrm{L}=5,264-$ $0,060 \times \mathrm{VEF}_{1} / \mathrm{CVF}\left(\mathrm{r}^{2}=0,33 ; \mathrm{r}^{2}\right.$ ajustado $\left.=0,32\right)$ e $\Delta \mathrm{VR}_{\mathrm{PCl}-\mathrm{DHRU}} \mathrm{em} \mathrm{L}=4,862-0,055 \times \mathrm{VEF}_{1} / \mathrm{CVF}\left(\mathrm{r}^{2}=0,31 ; \mathrm{r}^{2}\right.$ ajustado $=0,30$ ). Conclusões: A correção de $\mathrm{CPT}$ e VR obtidos por DHRU pode melhorar a acurácia desse método para avaliar os volumes pulmonares em pacientes com DVO. Entretanto, estudos adicionais para validar essas equações são necessários.

Descritores: Pletismografia total; Capacidade pulmonar total; Volume residual.

\footnotetext{
* Study carried out at the Porto Alegre Hospital de Clínicas, Porto Alegre, Brazil.

Correspondence to: Sérgio Saldanha Menna Barreto. HCPA, Rua Ramiro Barcelos, 2350, sala 2050, Bom Fim, CEP 90035-903, Porto Alegre, RS, Brasil.

Tel. 5586 3323-5209. E-mail: smenna@terra.com.br

Financial support: This study received financial support from the Fundo de Incentivo à Pesquisa do Hospital de Clínicas de Porto Alegre (FIPE-HCPA, Research Incentive Fund of the Porto Alegre Hospital de Clínicas).

Submitted: 15 February 2013. Accepted, after review: 26 September 2013.
} 


\section{Introduction}

Lung volume measurements are useful for characterizing the severity of respiratory diseases, evaluating the results of interventions, and determining prognosis. ${ }^{(1,2)}$ Patients with restrictive lung disease (RLD) can present with reduced TLC, whereas those with chronic obstructive lung disease (OLD) can present with increased TLC (usually as a result of increased RV). ${ }^{(3)}$ Various methods can be used in order to determine lung volumes, including whole-body plethysmography (WBP), gas dilution methods, and radiological techniques. ${ }^{(4-8)}$ Currently, WBP and the multiple-breath helium dilution method are used in pulmonary function laboratories in order to measure TLC and RV. Any of the abovementioned methods can be used provided that the equipment and maneuvers are in accordance with the recommended technical standards. ${ }^{(8,9)}$ However, WBP is considered the gold standard by some researchers. ${ }^{(10)}$

The single-breath helium dilution (SBHD) method is a simpler, cheaper, and more widely available alternative method for evaluating alveolar volume with equipment that is less complex than a plethysmograph, having the operational advantage of being performed in conjunction with DLCO determination. However, because the SBHD method depends on the air that is mobilized during a single respiratory maneuver, it can underestimate lung volumes when compared with WBP in patients with a markedly uneven distribution of ventilation. ${ }^{(11,12)}$ Although determination of alveolar volume by the SBHD method for measuring DLCO is used worldwide, the value of this technique in determining lung volumes in patients with OLD or RLD has yet to be established.

In view of the abovementioned considerations, the objective of the present study was to compare lung volumes as measured by the SBHD method with lung volumes as measured by WBP in individuals with normal lung function, as well as in patients with OLD or RLD of varying degrees of severity. In addition, we sought to develop equations to estimate TLC and RV as measured by WBP ( $T L C_{W B P}$ and $R V_{W B P}$, respectively) on the basis of TLC and RV as measured by the SBHD method $\left(\mathrm{TLC}_{\mathrm{SBHD}}\right.$ and $\mathrm{RV}_{\mathrm{SBHD}}$, respectively) and adjusted for the degree of airflow obstruction.

\section{Methods}

This was a retrospective cross-sectional study involving 142 consecutive patients who underwent spirometry, static lung volume measurements by WBP, and single-breath pulmonary diffusing capacity measurements in the pulmonary physiology laboratory of a referral hospital. We selected patients with OLD caused by COPD and patients in whom spirometry results were suggestive of RLD. We excluded patients whose spirometry results showed mixed obstructive and restrictive lung disease, indeterminate lung disease, or OLD of causes other than COPD. The control group $(n=27)$ comprised 8 patients (6 of whom were smokers) who had normal spirometry results and who had undergone WBP and pulmonary diffusing capacity measurements in routine care, as well as 19 volunteers who were recruited from the community, who were nonsmokers, who had no respiratory complaints or diseases, who had normal chest X-rays, and who had undergone the three tests in the same period in order to determine whether the reference standards used in the laboratory were appropriate. The ethical and methodological aspects of the study project were approved by the local research ethics committee.

We collected data regarding age (years), gender, weight $(\mathrm{kg})$, height $(\mathrm{cm})$, body mass index $\left(\mathrm{kg} / \mathrm{m}^{2}\right)$, and smoking history (pack-years). All pulmonary function tests were performed with a MasterScreen Body spirometer (Jäeger, Würzburg, Germany) and were in accordance with the technical recommendations in the Brazilian Thoracic Association guidelines for pulmonary function testing. ${ }^{(9)}$ Patients underwent spirometry, WBP, and DLCO testing always in the same sequence and at the same time of day. All tests were performed before and after the administration of $400 \mu \mathrm{g}$ of albuterol. We calculated $\mathrm{TLC}_{\mathrm{SBHD}}$ by summing the alveolar volume as measured by DLCO testing and the anatomical dead space. We calculated $\mathrm{RV}_{\text {SBHD }}$ by subtracting $\mathrm{FVC}$ from $\mathrm{TLC}_{\mathrm{SBHD}}$. The gases and plethysmograph were calibrated daily before test initiation. The reference values for spirometry, lung volumes, and DLCO were those described elsewhere. ${ }^{(13-15)}$

In order to confirm the diagnosis of COPD by spirometry, we used an FEV $/ F V C$ ratio after bronchodilator use $\leq 0.70 .{ }^{(16)}$ The severity of airflow obstruction was determined on the basis of $\mathrm{FEV}_{1}$, as recommended by the American Thoracic Society. ${ }^{(17)}$ Mild to moderate OLD was defined as an $\mathrm{FEV}_{1} \geq 50 \%$ of the predicted value; severe OLD was defined as an FEV ${ }_{1}$ of 35-49\% of the predicted value; and very severe OLD was defined 
as an $\mathrm{FEV}_{1}<35 \%$ of the predicted value. Only 5 patients presented with mild OLD. Therefore, they were evaluated in conjunction with those who presented with moderate OLD.

For the diagnosis of RLD, we used the following criteria: an $\mathrm{FEV}_{1} / \mathrm{FVC}$ ratio after bronchodilator use $>0.80$; reduced VC (an FVC $<80 \%$ of the predicted value); and reduced TLC (a TLC $<80 \%$ of the predicted value). For data analysis, we used the median in order to divide the patients with RLD into two groups according to the severity of the disease (a TLC $>72 \%$ of the predicted value indicating less severe disease and a TLC $<72 \%$ of the predicted value indicating more severe disease).

Statistical analysis was performed with the Statistical Analysis System software, version 9.1 (SAS Institute, Cary, NC, USA). The collected data were expressed as mean, SE, and 95\% $\mathrm{Cl}$. For the evaluation of variables with one observation, one-way ANOVA was performed to determine the differences among the groups. Whenever Levene's test revealed heterogeneity of variance, Welch's ANOVA was performed. For complementation of results, Tukey's test was performed. The possible influence of the covariates gender, age, weight, height, body mass index, and smoking history was tested by analysis of covariance. For the evaluation of variables for each lung function method, mixed-model ANOVA was performed. For complementation of significant effects in relation to the method and group, the Tukey-Kramer test was performed ( $p<0.05)$. The goodness of fit of the model was tested by analysis of residuals and determination of normality by the KolmogorovSmirnov test $(p>0.01)$, the Anderson-Darling test, and the Cramér-von Mises test ( $p>0.005)$. In both models, we obtained partial or residual Pearson correlations, eliminating the effect of factors in order to determine the association between variables.

Bland-Altman plots ${ }^{(18)}$ were used in order to determine the differences in TLC and RV between the two methods. The limits of agreement were calculated as \pm 1.96 SDs of the differences. We developed prediction equations to estimate the differences in TLC and RV between the two methods by means of stepwise multiple linear regression, variables with a value of $p<0.10$ being included in the models. For all analyses, we used the values obtained after bronchodilator use.

\section{Results}

In the present study, 169 individuals underwent spirometry and lung volume measurements by WBP and the SBHD method in an open system. Of the 169 individuals, 27 had normal spirometry results, 93 had OLD, and 49 had RLD. The patients with OLD were stratified as follows: patients with mild to moderate OLD (29 patients); patients with severe OLD (29 patients); and patients with very severe OLD ( 35 patients). The patients with RLD were stratified as follows: patients with less severe disease (25 patients); and patients with more severe disease (24 patients).

Anthropometric data, duration of smoking, smoking history, and pulmonary function test results, stratified by lung function status, are presented in Table 1.

Figure 1 shows mean TLC and RV (in absolute values and in percentage of predicted). In all groups, $\mathrm{TLC}_{\mathrm{WBP}}$ and $\mathrm{RV}_{\mathrm{WBP}}$ values were higher than $\mathrm{TLC}_{\mathrm{SBHD}}$ and $\mathrm{RV}_{\mathrm{SBHD}}$ values $(\mathrm{p}<0.01)$, the discrepancy between the two methods being most pronounced in the OLD group and the difference increasing progressively as the severity of airflow obstruction increased. A comparison between the RV/TLC ratio obtained by WBP and the RV/TLC ratio obtained by the SBHD method provided further evidence of the discrepancy between the two methods. In the individuals with normal lung function, those ratios were 0.36 and 0.29 , respectively. In the group of patients with mild to moderate OLD, those ratios were 0.53 and 0.38 , respectively; in the group of patients with severe OLD, those ratios were 0.60 and 0.43 , respectively; and in the group of patients with very severe OLD, those ratios were 0.66 and 0.47 , respectively. In the group of patients with less severe RLD, those ratios were 0.44 and 0.32 , respectively, and in the group of patients with more severe RLD, those ratios were 0.45 and 0.39 , respectively.

Table 2 shows the differences in TLC and RV between WBP and the SBHD method (in absolute values and in percentage of predicted) in the groups studied. In the groups of patients with RLD and normal spirometry results, the difference in TLC between the two methods ranged from $0.61 \mathrm{~L}$ to $0.80 \mathrm{~L}$ (from $10.8 \%$ of the predicted value to $13.1 \%$ of the predicted value; $p>0.05)$. In addition, the difference in RV between the two methods ranged from $0.52 \mathrm{~L}$ to $0.75 \mathrm{~L}$ (from $30.8 \%$ of the predicted value to 
Table 1 - Anthropometric characteristics, smoking history, and functional parameters in 169 individuals stratified by lung function status.

\begin{tabular}{|c|c|c|c|c|c|c|}
\hline \multirow[t]{4}{*}{ Variable } & \multicolumn{6}{|c|}{ Lung function status } \\
\hline & \multirow[t]{2}{*}{ Normal } & \multicolumn{3}{|c|}{ Obstructive lung disease } & \multicolumn{2}{|c|}{ Restrictive lung disease } \\
\hline & & $\begin{array}{c}\text { Mild/ } \\
\text { moderate }\end{array}$ & Severe & Very severe & Less severe & More severe \\
\hline & $(n=27)$ & $(n=29)$ & $(n=29)$ & $(n=35)$ & $(n=25)$ & $(n=24)$ \\
\hline Age, years & $46.40 \pm 13.70^{b}$ & $64.90 \pm 8.88^{\mathrm{a}}$ & $70.10 \pm 6.62^{\mathrm{a}}$ & $65.80 \pm 8.78^{\mathrm{a}}$ & $47.30 \pm 15.90^{b}$ & $54.42 \pm 21.36^{b}$ \\
\hline Weight, kg & $66.60 \pm 16.13^{\mathrm{a}}$ & $71.20 \pm 13.21^{\mathrm{a}}$ & $68.40 \pm 12.95^{\mathrm{a}}$ & $66.60 \pm 13.94^{\mathrm{a}}$ & $70.50 \pm 9.90^{\mathrm{a}}$ & $66.53 \pm 14.71^{\mathrm{a}}$ \\
\hline Height, cm & $161.00 \pm 11.28^{\mathrm{a}}$ & $161.00 \pm 9.20^{\mathrm{a}}$ & $163.00 \pm 8.63^{\mathrm{a}}$ & $166.00 \pm 9.09^{a}$ & $1.62 \pm 6.69^{\mathrm{a}}$ & $1.63 \pm 8.32^{\mathrm{a}}$ \\
\hline $\mathrm{BMl}, \mathrm{kg} / \mathrm{m}^{2}$ & $25.50 \pm 6.23^{\mathrm{a}}$ & $27.30 \pm 4.46^{\mathrm{a}}$ & $25.70 \pm 3.37^{\mathrm{a}}$ & $24.20 \pm 4.03^{\mathrm{a}}$ & $27.10 \pm 4.14^{\mathrm{a}}$ & $25.08 \pm 5.16^{\mathrm{a}}$ \\
\hline $\begin{array}{l}\text { Duration of } \\
\text { smoking, years }\end{array}$ & $5.89 \pm 11.50^{b}$ & $41.86 \pm 12.01^{\mathrm{a}}$ & $44.86 \pm 9.17^{\mathrm{a}}$ & $36.40 \pm 12.56^{\mathrm{a}}$ & $10.60 \pm 13.37^{b}$ & $12.17 \pm 17.57^{b}$ \\
\hline $\begin{array}{l}\text { Smoking history, } \\
\text { pack-years }\end{array}$ & $1.27 \pm 2.10^{\mathrm{b}}$ & $62.20 \pm 37.35^{\mathrm{a}}$ & $59.00 \pm 38.69^{a}$ & $54.70 \pm 35.34^{\mathrm{a}}$ & $12.30 \pm 17.86^{b}$ & $20.98 \pm 43.25^{b}$ \\
\hline FVC, L & $3.55 \pm 1.10^{\mathrm{a}}$ & $2.82 \pm 0.81^{\mathrm{b}}$ & $2.30 \pm 0.54^{c}$ & $2.27 \pm 0.57^{c}$ & $2.20 \pm 0.42^{\text {cd }}$ & $1.89 \pm 0.46^{\mathrm{d}}$ \\
\hline $\begin{array}{l}\text { FVC, } \% \text { of } \\
\text { predicted }\end{array}$ & $98.32 \pm 12.96^{a}$ & $81.86 \pm 13.76^{b}$ & $67.70 \pm 10.97^{c}$ & $60.23 \pm 11.58^{c}$ & $62.07 \pm 7.65^{c}$ & $51.91 \pm 6.81^{d}$ \\
\hline $\mathrm{FEV}_{1}, \mathrm{~L}$ & $3.06 \pm 0.92^{\mathrm{a}}$ & $1.66 \pm 0.51^{b}$ & $1.14 \pm 0.29^{c}$ & $0.82 \pm 0.19^{d}$ & $1.96 \pm 0.37^{b}$ & $1.70 \pm 0.43^{b}$ \\
\hline $\begin{array}{l}\mathrm{FEV}_{1}, \% \text { of } \\
\text { predicted }\end{array}$ & $10.99 \pm 12.92^{\mathrm{a}}$ & $63.19 \pm 10.95^{b c}$ & $42.41 \pm 4.96^{d}$ & $27.59 \pm 4.97^{e}$ & $67.34 \pm 8.03^{b}$ & $58.01 \pm 9.43^{c}$ \\
\hline $\mathrm{FEV}_{1} / \mathrm{FVC}$ & $85.35 \pm 4.55^{\mathrm{a}}$ & $58.80 \pm 6.60^{b}$ & $49.85 \pm 8.60^{c}$ & $36.90 \pm 7.92^{\mathrm{d}}$ & $89.61 \pm 4.82^{\mathrm{a}}$ & $89.73 \pm 5.13^{\mathrm{a}}$ \\
\hline $\begin{array}{l}\text { DLCO, } \mathrm{mL} . \\
\min ^{-1} \cdot \mathrm{mmHg}^{-1}\end{array}$ & $23.67 \pm 6.15^{a}$ & $13.04 \pm 4.32^{\mathrm{b}}$ & $10.39 \pm 4.09^{c}$ & $8.85 \pm 3.47^{d}$ & $11.03 \pm 4.38^{\mathrm{cd}}$ & $9.71 \pm 5.86^{\mathrm{cd}}$ \\
\hline $\begin{array}{l}\text { DLC0, } \% \text { of } \\
\text { predicted }\end{array}$ & $86.42 \pm 14.47^{a}$ & $56.41 \pm 15.31^{\mathrm{b}}$ & $46.27 \pm 15.53^{b c}$ & $36.25 \pm 14.65^{d}$ & $41.51 \pm 13.22^{\text {cd }}$ & $37.05 \pm 17.50^{\text {cd }}$ \\
\hline DLCO/AV & $4.98 \pm 0.61^{\mathrm{a}}$ & $2.85 \pm 0.58^{b}$ & $2.48 \pm 0.89^{b c}$ & $2.10 \pm 0.80^{c}$ & $3.68 \pm 1.14^{b}$ & $3.23 \pm 1.49^{b}$ \\
\hline $\begin{array}{l}\text { DLCO/AV, \% of } \\
\text { predicted }\end{array}$ & $94.04 \pm 24.12^{\mathrm{a}}$ & $66.27 \pm 15.08^{b}$ & $63.91 \pm 24.25^{b c}$ & $51.61 \pm 21.04^{c}$ & $71.66 \pm 19.86^{b}$ & $69.42 \pm 27.20^{b}$ \\
\hline
\end{tabular}

BMI: body mass index; and AV: alveolar volume. Values presented as mean \pm SD. Matching letters indicate absence of significant difference between groups, whereas non-matching letters indicate significant difference between groups. One-way ANOVA (groups); $\mathrm{p}<0.05$.

$43.4 \%$ of the predicted value; $p>0.05)$. In the groups of patients with mild to moderate OLD and severe OLD, the difference in TLC between the two methods ranged from $1.58 \mathrm{~L}$ to $2.00 \mathrm{~L}$ (from $30.5 \%$ of the predicted value to $38.2 \%$ of the predicted value; $p>0.05$ ), and the difference in RV between the two methods ranged from $1.46 \mathrm{~L}$ to $2.03 \mathrm{~L}$ (from $80.7 \%$ of the predicted value to $99.4 \%$ of the predicted value; $p>0.05$ ). The group of patients with very severe OLD differed from all of the other groups analyzed, showing the largest differences between the two methods regarding TLC $(3.09 \mathrm{~L}$; 50.4\% of the predicted value) and RV (2.89 L; 139.5\% of the predicted value).

The correlations between $\mathrm{FEV}_{1} / \mathrm{FVC}$ and the differences in TLC and RV values between the two methods in the individuals with normal spirometry results, in the patients with OLD, and in the patients with RLD are shown in
Figure 2 (panels A, B, and C, respectively). The best correlations were observed in the group of patients with OLD $\left(r=-0.47\right.$ for $\Delta$ TLC $_{\text {WBP-SBHD }}$ in $\%$ of predicted and $r=-0.54$ for $\Delta R V_{\text {WBP-SBHD }}$ in $\%$ of predicted). When the individuals with normal spirometry results and the patients with OLD were analyzed as a whole, the correlation between $\mathrm{FEV}_{1}$ in $\%$ of predicted and $\triangle \mathrm{TLC}_{\text {WBP-SBHD }}$ in $\%$ of predicted increased to $r=-0.61$ ( $p<$ 0.0001 ), as did the correlation between $\mathrm{FEV}_{1}$ in $\%$ of predicted and $\Delta \mathrm{RV}_{\text {WBP-SBHD }}$ in $\%$ of predicted $(r=-0.640 ; p<0.0001)$.

The association between $\mathrm{TLC}_{\mathrm{WBP}}$ and $\mathrm{TLC}_{\mathrm{SBHD}}$ was assessed by Pearson's correlation test. For the sample as a whole $(n=169)$, there was a moderate positive correlation between $\mathrm{TLC}_{\mathrm{WBP}}$ and $\mathrm{TLC}_{\mathrm{SBHD}}$ $(r=0.71 ; p<0.001)$, as well as between $R V_{\text {WBP }}$ and $\mathrm{RV}_{\mathrm{SBHD}}(\mathrm{r}=0.62 ; \mathrm{p}<0.0001)$. In the group of individuals with normal spirometry results and in that of patients with RLD, the coefficients 

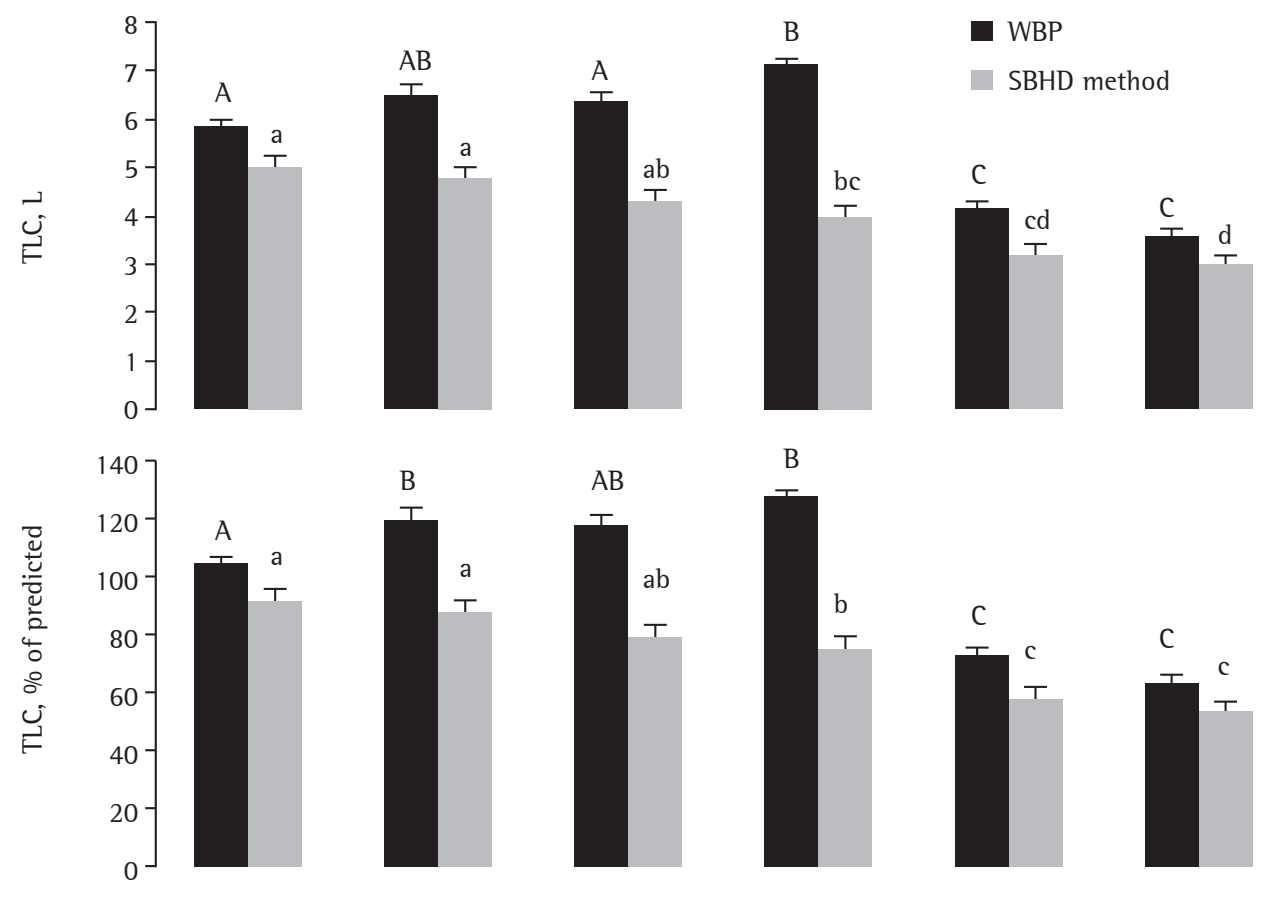

B
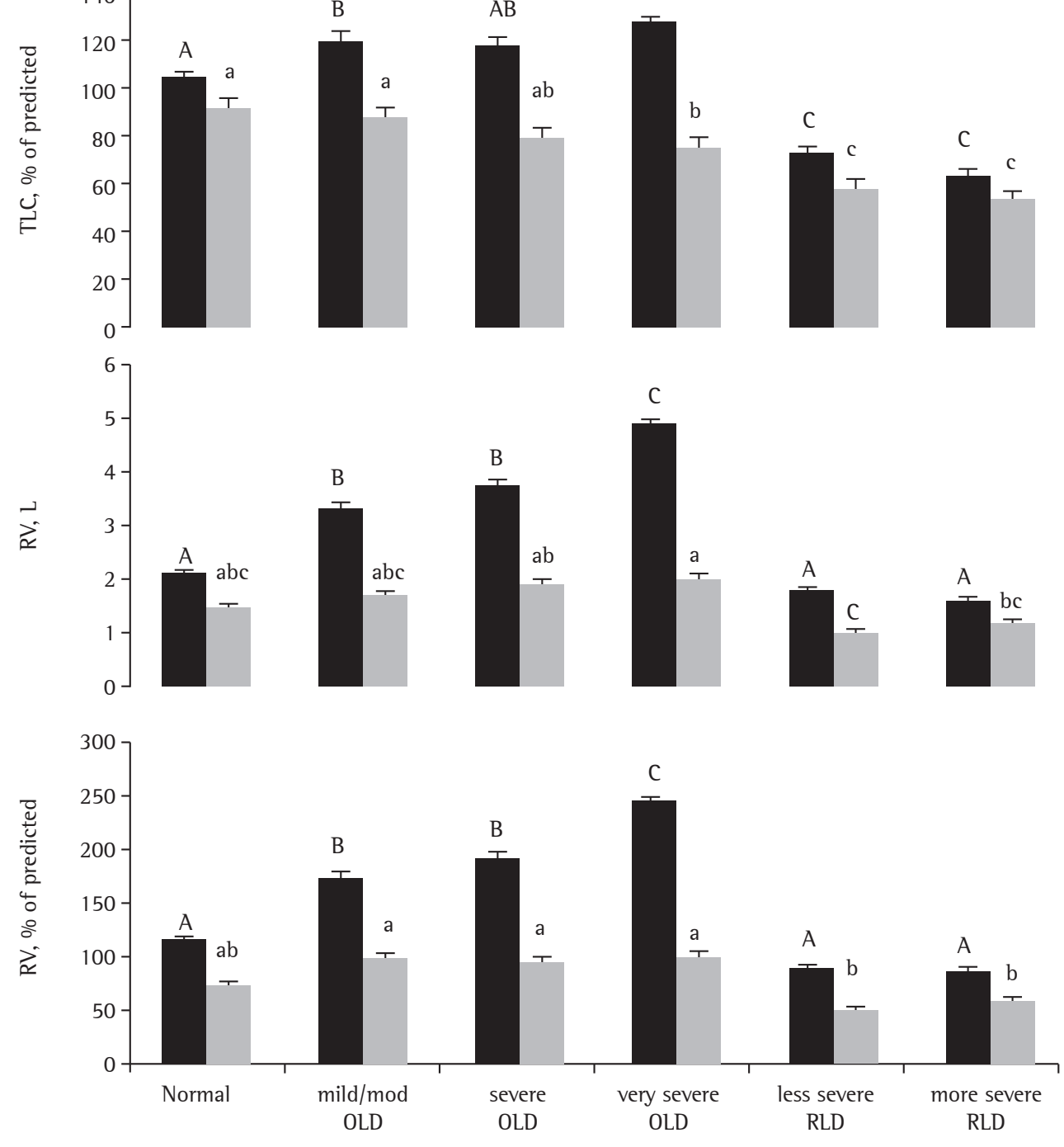

Figure 1 - Comparison of TLC and RV values as measured by whole-body plethysmography (WBP) with TLC and RV values as measured by the single-breath helium dilution (SBHD) method (in absolute values and in percentage of predicted) in different groups of patients, stratified by lung function status. In all groups, the TLC and RV values obtained by WBP were higher than those obtained by the SBHD method $(p<0.01)$. OLD: obstructive lung disease; mild/mod: mild/moderate; and RLD: restrictive lung disease. Capital letters represent comparisons of values obtained by WBP, whereas lower-case letters represent comparisons of values obtained by the SBHD method. Matching letters indicate absence of statistically significant differences. Two-way ANOVA (methods and groups); $p<0.05$. 
Table 2 - Differences between TLC and RV values as measured by whole-body plethysmography and TLC and RV values as measured by the single-breath helium dilution method in 169 individuals stratified by lung function status.

\begin{tabular}{|c|c|c|c|c|c|c|}
\hline \multirow[t]{4}{*}{ Variable } & \multicolumn{6}{|c|}{ Lung function status } \\
\hline & \multirow[t]{2}{*}{ Normal } & \multicolumn{3}{|c|}{ Obstructive lung disease } & \multicolumn{2}{|c|}{ Restrictive lung disease } \\
\hline & & Mild/moderate & Severe & Very severe & Less severe & More severe \\
\hline & $(\mathrm{n}=27)$ & $(n=29)$ & $(n=29)$ & $(n=35)$ & $(n=25)$ & $(n=24)$ \\
\hline$\Delta \mathrm{TLC}_{\text {WBP-SBHD}}, \mathrm{L}$ & $\begin{array}{c}0.74 \\
(0.36-0.74)^{a}\end{array}$ & $\begin{array}{c}1.58 \\
(1.27-2.25)^{\mathrm{b}}\end{array}$ & $\begin{array}{c}2.00 \\
(0.95-3.31)^{\mathrm{b}}\end{array}$ & $\begin{array}{c}3.09 \\
(2.25-4.01)^{\mathrm{c}}\end{array}$ & $\begin{array}{c}0.80 \\
(0.61-1.04)^{\mathrm{a}}\end{array}$ & $\begin{array}{c}0.61 \\
(0.35-0.95)^{a}\end{array}$ \\
\hline $\begin{array}{l}\Delta \mathrm{TLC}_{\text {WBP-SBHD}} \\
\% \text { of predicted }\end{array}$ & $\begin{array}{c}13.12 \\
(8.40-21.20)^{\mathrm{ab}}\end{array}$ & $\begin{array}{c}30.50 \\
(22.42-38.85)^{\mathrm{bc}}\end{array}$ & $\begin{array}{c}38.30 \\
(19.70-50.40)^{c}\end{array}$ & $\begin{array}{c}50.40 \\
(40.13-65.90)^{d}\end{array}$ & $\begin{array}{c}16.13 \\
(11.00-20.00)^{\mathrm{ab}}\end{array}$ & $\begin{array}{c}10.85 \\
(7.15-16.90)^{\mathrm{a}}\end{array}$ \\
\hline$\Delta \mathrm{RV}_{\text {WBP-SBHD }}, \mathrm{L}$ & $\begin{array}{c}0.62 \\
(0.13-0.92)^{\mathrm{a}}\end{array}$ & $\begin{array}{c}1.46 \\
(1.07-1.97)^{b}\end{array}$ & $\begin{array}{c}2.03 \\
(0.84-2.83)^{b}\end{array}$ & $\begin{array}{c}2.89 \\
(2.03-3.82)^{c}\end{array}$ & $\begin{array}{c}0.75 \\
(0.49-0.93)^{\mathrm{a}}\end{array}$ & $\begin{array}{c}0.52 \\
(0.23-0.79)^{a}\end{array}$ \\
\hline $\begin{array}{l}\Delta \mathrm{RV}_{\text {WBP-SBHD }}, \% \\
\text { of predicted }\end{array}$ & $\begin{array}{c}34.70^{\mathrm{a}} \\
(11.40-53.30)\end{array}$ & $\begin{array}{c}80.70 \\
(54.39-103.45)^{\mathrm{b}}\end{array}$ & $\begin{array}{c}99.38 \\
(53.20-137.15)^{b}\end{array}$ & $\begin{array}{c}139.50 \\
(109.20-167.30)^{c}\end{array}$ & $\begin{array}{c}43.40 \\
(28.60-56.35)^{a}\end{array}$ & $\begin{array}{c}30.80 \\
(19.88-44.20)^{a}\end{array}$ \\
\hline
\end{tabular}

WBP: whole-body plethysmography; and SBHD: single-breath helium dilution method. Data presented as median delta and 25-75\% interquartile range. Matching letters indicate absence of significant difference between groups, whereas non-matching letters indicate significant difference between groups. One-way ANOVA (groups); $p<0.05$.
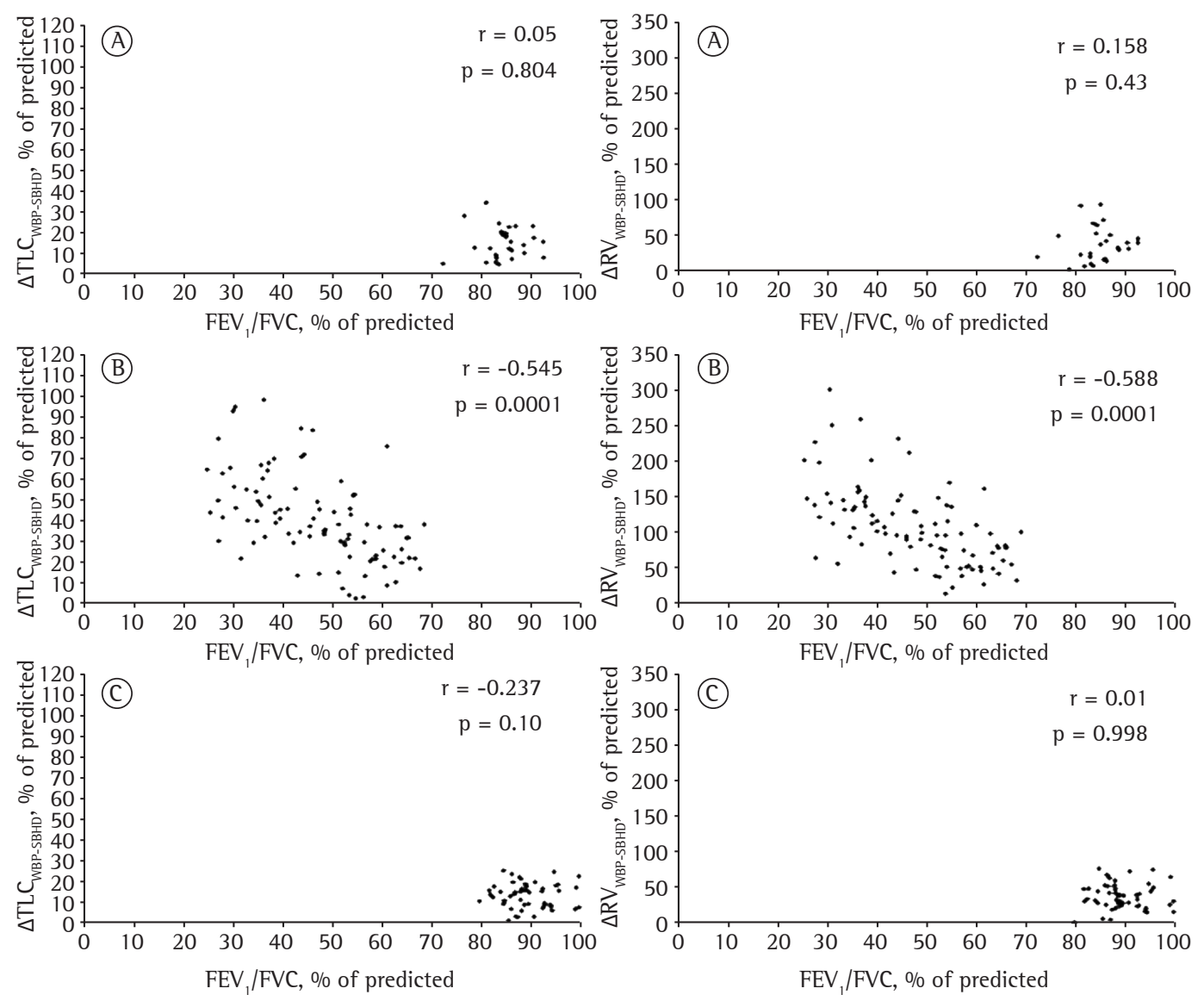

Figure 2 - Correlations of the difference between TLC as measured by whole-body plethysmography (WBP) and TLC as measured by the single-breath helium dilution (SBHD) method (left column), as well as of the difference between RV as measured by WBP and RV as measured by the SBHD method (right column), with the $\mathrm{FEV}_{1} / \mathrm{FVC}$ ratio in \% in individuals with normal lung function $(\mathrm{A})$, in patients with obstructive lung disease (B), and in patients with restrictive lung disease (C). 
of correlation between $\mathrm{TLC}_{\mathrm{WBP}}$ and $\mathrm{TLC}_{\mathrm{SBHD}}$ and between $\mathrm{RV}_{\mathrm{WBP}}$ and $\mathrm{RV}_{\mathrm{SBHD}}$ were, respectively, 0.92 and 0.51 ( $p<0.001)$, whereas in the group of patients with OLD, those correlation coefficients were, respectively, 0.55 and $0.36(p<0.001)$.

We used Bland-Altman plots in order to compare $\mathrm{TLC}_{\mathrm{WBP}}$ with $\mathrm{TLC}_{\mathrm{SBHD}}$ and $\mathrm{RV}_{\mathrm{WBP}}$ with $\mathrm{RV}_{\mathrm{SBHD}}$. The data are shown separately for each group, by lung function status, in Figure 3 . The group of patients with RLD showed the smallest difference between the two methods for both variables; the largest differences were observed in the patients with OLD and higher lung volumes.

For the sample as a whole $(n=169)$, the difference in TLC values between the two methods was associated with the $\mathrm{FEV}_{1} / \mathrm{FVC}$ ratio $(\mathrm{r}=$ $-0.75 ; p<0.001)$, FEV $_{1}(r=-0.51 ; p<0.001)$, and DLCO $(r=-0.39 ; p<0.001)$. Likewise, the difference in RV values between the two methods correlated with the $\mathrm{FEV}_{1} / \mathrm{FVC}$ ratio $(\mathrm{r}=-0.75$; $p<0.0001), \operatorname{FEV}_{1}(r=-0.53 ; p<0.0001)$, and DLCO $(r=-0.41 ; p<0.0001)$. There was no significant correlation between the difference in lung volumes and FVC $(p>0.05)$. For the 93 patients with OLD, the coefficient of correlation between $\mathrm{TLC}_{\mathrm{WBP}}$ and $\mathrm{TLC}_{\mathrm{SBHD}}$ was $0.57(\mathrm{p}<0.001)$ and the coefficient of correlation between $\mathrm{RV}_{\mathrm{WBP}}$ and $\mathrm{RV}_{\mathrm{SBHD}}$ was $0.56(\mathrm{p}<0.001)$. In the patients with OLD, we used a regression equation in order to predict $\mathrm{TLC}_{\mathrm{WBP}}$ and $\mathrm{RV}_{\mathrm{WBP}}$ on the basis of $\mathrm{TLC}_{\mathrm{SBHD}}$ and $\mathrm{RV}_{\mathrm{SBHD}}$. The $\mathrm{FEV}_{1} / \mathrm{FVC}$ ratio (\%),

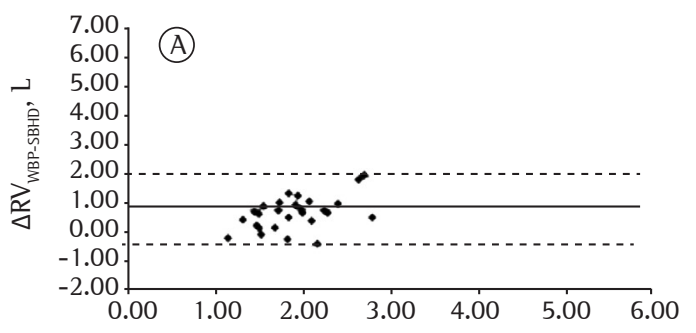

Mean of the TLC values obtained by the two methods, $\mathrm{L}$ Mean of the RV values obtained by the two methods, $\mathrm{L}$
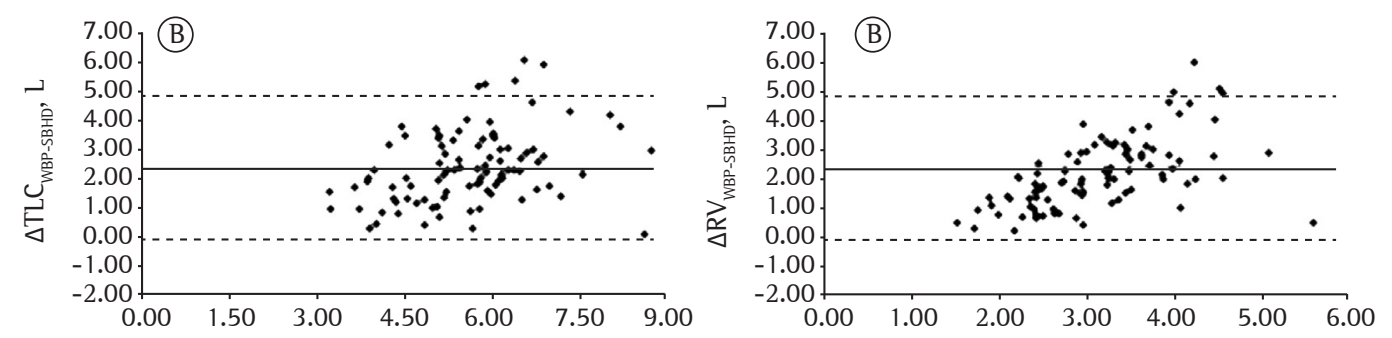

Mean of the TLC values obtained by the two methods, $\mathrm{L}$
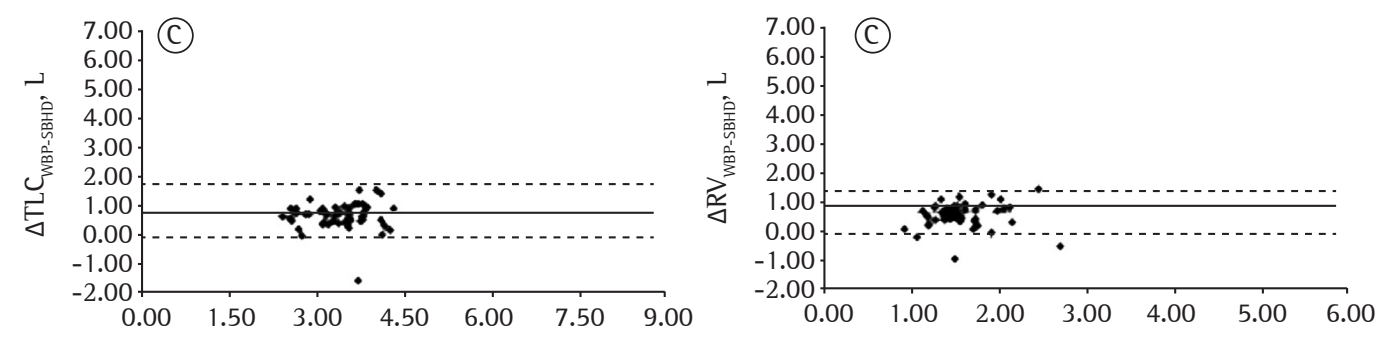

Mean of the TLC values obtained by the two methods, $\mathrm{L}$

Mean of the RV values obtained by the two methods, $\mathrm{L}$

Figure 3 - Bland-Altman plots of the difference between TLC as measured by whole-body plethysmography (WBP) and TLC as measured by the single-breath helium dilution (SBHD) method (left column), as well as of the difference between RV as measured by WBP and RV as measured by the SBHD method (right column), in function of the mean of the TLC values (in L) obtained by the two methods (left column) and of the mean of the RV values (in L) obtained by the two methods (right column) in individuals with normal lung function (A), in patients with obstructive lung disease (B), and in patients with restrictive lung disease (C). The solid line represents the mean, and the dashed lines represent the SD $( \pm 1.96)$. 
$\mathrm{FEV}_{1}(\mathrm{~L})$, and DLCO $\left(\mathrm{mL} \cdot \mathrm{min}^{-1} \cdot \mathrm{mmHg}^{-1}\right)$ were included in the models. In the univariate analysis for $\triangle T L C_{\text {WBP-SBHD }}$, the adjusted coefficients for $\mathrm{FEV}_{1} / \mathrm{FVC}, \mathrm{FEV}_{1}$, and DLCO were, respectively, $r^{2}=0.32, r^{2}=0.14$, and $r^{2}=0.07$, whereas for $\Delta R V_{\text {WBP-SBHD }}$, the adjusted coefficients for the same variables were, respectively, $\mathrm{r}^{2}=0.30, \mathrm{r}^{2}=0.14$, and $r^{2}=0.07$. In the multivariate analysis, FEV and DLCO lost significance and were excluded from the models. The regression equation to predict the difference in TLC between the two methods in the patients with OLD was as follows:

$y=5.264-0.060 x$

where $\mathrm{y}=\Delta \mathrm{TLC}_{\text {WBP-SBHD }}$ in $\mathrm{L}$ and $\mathrm{x}=\mathrm{FEV}_{1} / \mathrm{FVC}$ in $\%\left(r^{2}=0.33\right.$; adjusted $\left.r^{2}=0.32\right)$.

The regression equation to predict the difference in RV between the two methods was as follows:

$Y=4.862-0.055 x$

where $\mathrm{Y}=\Delta \mathrm{RV}_{\text {WBP-SBHD }}$ in $\mathrm{L}$ and $\mathrm{x}=\mathrm{FEV}_{1} / \mathrm{FVC}$ in $\%\left(r^{2}=0.31\right.$; adjusted $\left.r^{2}=0.30\right)$.

We were unable to develop equations for individuals with normal lung function and those with RLD.

\section{Discussion}

Our results showed the following: 1) $\mathrm{TLC}_{\mathrm{WBP}}$ and $\mathrm{RV}_{\mathrm{WBP}}$ values were higher than $\mathrm{TLC}_{\mathrm{SBHD}}$ and $\mathrm{RV}_{\mathrm{SBHD}}$ values, regardless of the lung function status; 2) the magnitude of the difference in lung volumes between the two methods was associated with the $\mathrm{FEV}_{1} / \mathrm{FVC}$ ratio, progressively increasing with the degree of airflow obstruction; 3) lung volumes as measured by WBP can be estimated on the basis of the values obtained by the SBHD method provided that the values are corrected for the severity of airflow obstruction.

Our study showed that, in the individuals with normal lung function and in those with RLD, the SBHD method underestimated lung volumes when compared with WBP. Comparable values between the two techniques ${ }^{(7)}$ or a difference of $0.21 \mathrm{~L}$ in TLC in individuals with normal spirometry results have previously been described. ${ }^{(12)}$ In another study, when compared with the multiple-breath helium dilution method, WBP overestimated TLC by $0.47 \mathrm{~L}$ or $7.2 \%$ in normal individuals. ${ }^{(19)}$

In the OLD patients in the present study, the difference between the lung volumes obtained by WBP and those obtained by the SBHD method increased or decreased proportionally to the increase in airflow obstruction and air trapping. Various studies have compared lung volumes as measured by different methods in patients with OLD. Garfield et al. ${ }^{(20)}$ compared TLC as measured by plethysmography with TLC as measured by chest HRCT in patients with COPD and found a difference of $1.12 \mathrm{~L}(17.3 \%)$ between the two. Similarly, O'Donnell et al. ${ }^{(5)}$ showed that, in patients with COPD, WBP systematically overestimates lung volumes in comparison with the multiple-breath helium dilution method and CT, and that the discrepancy is most pronounced in individuals with $\mathrm{FEV}_{1}<30 \%$ of the predicted value. In contrast, in 815 males with mild airflow obstruction, the SBHD method underestimated $\mathrm{TLC}_{\mathrm{WBP}}$ by $0.75 \mathrm{~L}^{\left({ }^{(19)}\right.}$ A difference of up to $1.08 \mathrm{~L}$ has been reported between $\mathrm{TLC}_{\mathrm{WBP}}$ and TLC as measured by the multiple-breath helium dilution method..$^{(5,19,21,22)}$ Major discrepancies (of up to $2.25 \mathrm{~L}$ ) have been observed between $\mathrm{TLC}_{\mathrm{SBHD}}$ and TLC as measured by the multiple-breath helium dilution method in the presence of OLD. ${ }^{(12,23)}$

The different results across studies might be related to the cause of OLD, the varying degrees of airflow obstruction, and, in particular, the methods used in order to measure lung volumes. In addition to measuring the ventilated volume, plethysmography measures areas of air trapping. Conversely, the helium dilution technique measures only the air that is ventilated. In patients with airflow obstruction, there are variations in time constants of the respiratory system and in the distribution of ventilation, and there is early collapse of the airways during exhalation, which impairs lung emptying and causes air trapping. These physiological abnormalities help to explain the difference between the values obtained by WBP and those obtained by the SBHD method or the multiple-breath helium dilution method in individuals with OLD. ${ }^{(7,24)}$

The two helium dilution methods differ in terms of lung volume measurements. The SBHD method is a fast and simple technique in which only one ventilatory maneuver is used (in order to determine DLCO). ${ }^{(25)}$ In addition, the SBHD method requires less effort from patients during pulmonary function testing..$^{(7,23,26)}$ In contrast, the multiple-breath helium dilution method requires a longer test time, allowing a more even distribution of the inhaled gas so that it is in equilibrium with the alveolar air. ${ }^{(7,26)} \mathrm{A}$ comparison between 
the two techniques showed that they provide comparable results in individuals without airflow obstruction but show differences of up to 34\% in patients with more severe obstruction. ${ }^{(7,12,19)}$

One of the statistical resources that we used in order to compare the findings of WBP with those of the SBHD method was the linear correlation test. The test showed a correlation of 0.92 in the individuals with normal spirometry results or RLD and of 0.55 in the patients with OLD. A correlation of 0.98 between $\mathrm{TLC}_{\mathrm{WBP}}$ and $\mathrm{TLC}_{\mathrm{SBHD}}$ in 32 normal individuals and of 0.70 between $\mathrm{TLC}_{\mathrm{WBP}}$ and $\mathrm{TLC}_{\mathrm{SBHD}}$ in patients with OLD had previously been reported. ${ }^{(27)}$ However, in our study, Bland-Altman plots ${ }^{(18)}$ were used for analysis of the lung volumes as measured by the two methods and showed that, despite a strong correlation between the two in the individuals with normal spirometry results, there was discordance between the two methods in that group of patients. The concordance between the two methods for determining lung volumes was better in the group of patients with RLD, as evidenced by a narrower $95 \% \mathrm{Cl}$ and a higher concentration of data around the mean. In contrast, in the group of patients with OLD, the difference between the two methods was more pronounced, especially in the patients with high lung volumes. The limitations of using linear correlation in order to evaluate the performance of two methods for measuring the same variable have previously been described, as have the advantages of using Bland-Altman plots in such cases. ${ }^{(22)}$

The linear regression equations that allow us to estimate $\mathrm{TLC}_{\mathrm{WBP}}$ and $\mathrm{RV}_{\mathrm{WBP}}$ values on the basis of $\mathrm{TLC}_{\mathrm{SBHD}}$ and $\mathrm{RV}_{\mathrm{SBHD}}$ values adjusted for the degree of airflow obstruction constitute an important contribution of our study. These equations can be used in patient care in situations in which only spirometry and pulmonary diffusing capacity testing are available. Although equations for TLC adjusted for the degree of airflow obstruction have previously been described, ${ }^{(7)}$ the gold standard used was the multiple-breath helium dilution technique rather than WBP. Considering the coefficients of determination for the regression equations developed in our study, we emphasize that most of the difference between the two methods remains unexplained.

One limitation of our study is its retrospective nature. The number of patients with mild OLD in the present study was very small, reflecting the profile of patients treated at a referral university hospital. Likewise, the number of patients with severe RLD was small, which limited the stratification of RLD patients. In addition, $\mathrm{RV}_{\mathrm{SBHD}}$ was obtained by subtracting FVC from $\mathrm{TLC}_{\mathrm{SBH}}$; the use of FVC instead of slow VC possibly contributed to the lower accuracy of the method, especially in the patients with OLD. Furthermore, the prediction equations should be validated in other patient populations in order to increase the external validity of the study.

In conclusion, our study demonstrated that $\mathrm{TLC}_{\mathrm{WBP}}$ and $\mathrm{RV}_{\mathrm{WBP}}$ values were higher than $\mathrm{TLC}_{\mathrm{SBH}}$ and $\mathrm{RV}_{\mathrm{SBHD}}$ values in normal individuals and in patients with RLD or OLD. The discrepancy between the two methods for measuring lung volumes was most pronounced in the group of patients with OLD caused by COPD, the magnitude of the difference being directly associated with the degree of airflow obstruction. The linear regression equations described in the present study allow us to adjust $\mathrm{TLC}_{\mathrm{SBHD}}$ and $\mathrm{RV}_{\mathrm{SBHD}}$ values for airflow, predicting the lung volumes as measured by WBP. Therefore, the relatively simple, faster, and more widely available SBHD method, used in order to determine pulmonary diffusing capacity, has potential for expanded use. However, additional studies are needed in order to validate the equations before they can be used in clinical practice.

\section{References}

1. Martinez FJ, de Oca MM, Whyte Rl, Stetz J, Gay SE, Celli BR. Lung-volume reduction improves dyspnea, dynamic hyperinflation, and respiratory muscle function. Am J Respir Crit Care Med. 1997;155(6):1984-90. http:// dx.doi.org/10.1164/ajrccm.155.6.9196106 PMid:9196106

2. Casanova C, Cote C, de Torres JP, Aguirre-Jaime A, Marin JM, Pinto-Plata V, et al. Inspiratory-to-total lung capacity ratio predicts mortality in patients with chronic obstructive pulmonary disease. Am J Respir Crit Care Med. 2005;171(6):591-7. http://dx.doi.org/10.1164/ rccm.200407-8670C PMid:15591470

3. Menna Barreto SS. Volumes pulmonares. J Pneumol. 2002;28(Suppl3):S83-S94.

4. Cazzola M, Rogliani P, Curradi G, Segreti A, Ciaprini C, Pezzuto G, et al. A pilot comparison of helium dilution and plethysmographic lung volumes to assess the impact of a long-acting bronchodilator on lung hyperinflation in COPD. Pulm Pharmacol Ther. 2009;22(6):522-5. http:// dx.doi.org/10.1016/j.pupt.2009.05.005 PMid:19481169

5. O‘Donnell CR, Bankier AA, Stiebellehner L, Reilly JJ, Brown R, loring SH. Comparison of plethysmographic and helium dilution lung volumes: which is best for COPD? Chest. 2010;137(5):1108-15. http://dx.doi.org/10.1378/ chest.09-1504 PMid:20022972 PMCid:PMC2862399 
6. Pappas GP, Brodkin CA, Sheppard L, Balmes J, Horike $\mathrm{M}$, Barnhart S. The validity of radiographic estimation of total lung capacity in patients with respiratory disease. Chest. 1998;114(2):513-20. http://dx.doi.org/10.1378/ chest.114.2.513 PMid:9726739

7. Punjabi NM, Shade D, Wise RA. Correction of singlebreath helium lung volumes in patients with airflow obstruction. Chest. 1998;114(3):907-18. http://dx.doi. org/10.1378/chest.114.3.907 PMid:9743183

8. Wanger J, Clausen JL, Coates A, Pedersen OF, Brusasco $\mathrm{V}$, Burgos F, et al. Standardisation of the measurement of lung volumes. Eur Respir J. 2005;26(3):511-22. http:// dx.doi.org/10.1183/09031936.05.00035005 PMid:16135736

9. Menna Barreto SS, Cavalazzi AC. Determinação dos volumes pulmonares: métodos de mensuração dos volumes pulmonares. J Pneumol. 2002;28(Suppl3):S95-S100.

10. Crapo RA. Pulmonary function testing. In: Baum GL, Crapo JD, GlassRoth J, Karlinsky JB, Celli BR. Textbook of Pulmonary Disease. Philadelphia: Lippincott-Raven; 1998. p. 199-218.

11. Kilburn KH, Miller A, Warshaw RH. Measuring lung volumes in advanced asbestosis: comparability of plethysmographic and radiographic versus helium rebreathing and single breath methods. Respir Med. 1993;87(2):115-20. http:// dx.doi.org/10.1016/0954-6111(93)90138-P

12. Milite F, Lederer DJ, Weingarten JA, Fani P, Mooney AM, Basner RC. Quantification of single-breath underestimation of lung volume in emphysema. Respir Physiol Neurobiol. 2009;165(2-3):215-20. http://dx.doi.org/10.1016/j. resp.2008.12.009 PMid:19150417 PMCid:PMC2759678

13. Pereira CA, Sato T, Rodrigues SC. New reference values for forced spirometry in white adults in Brazil. J Bras Pneumol. 2007;33(4):397-406. http://dx.doi.org/10.1590/ S1806-37132007000400008 PMid:17982531

14. Crapo RO, Morris AH. Standardized single breath normal values for carbon monoxide diffusing capacity. Am Rev Respir Dis. 1981;123(2):185-9. PMid:7235357

15. Crapo RO, Morris AH, Clayton PD, Nixon CR. Lung volumes in healthy nonsmoking adults. Bull Eur Physiopathol Respir. 1982;18(3):419-25. PMid:7074238

16. Vestbo J, Hurd SS, Agustí AG, Jones PW, Vogelmeier C, Anzueto A, et al. Global strategy for the diagnosis, management, and prevention of chronic obstructive pulmonary disease: GOLD executive summary. Am J Respir Crit Care Med. 2013;187(4):347-65. http://dx.doi. org/10.1164/rccm.201204-0596PP PMid:22878278

17. Pellegrino R, Viegi G, Brusasco V, Crapo RO, Burgos F, Casaburi R, et al. Interpretative strategies for lung function tests. Eur Respir J. 2005;26(5):948-68. http://dx.doi. org/10.1183/09031936.05.00035205 PMid:16264058
18. Bland JM, Altman DG. Statistical methods for assessing agreement between two methods of clinical measurement. Lancet. 1986;1(8476):307-10. http://dx.doi.org/10.1016/ S0140-6736(86)90837-8

19. Cliff 1J, Evans AH, Pantin CF, Baldwin DR. Comparison of two new methods for the measurement of lung volumes with two standard methods. Thorax. 1999;54(4):329-33. http://dx.doi.org/10.1136/thx.54.4.329 PMid:10092694 PMCid:PMC1745479

20. Garfield JL, Marchetti N, Gaughan JP, Steiner RM, Criner GJ. Total lung capacity by plethysmography and high-resolution computed tomography in COPD. Int J Chron Obstruct Pulmon Dis. 2012;7:119-26. http:// dx.doi.org/10.2147/COPD.S26419 PMid:22399851 PMCid:PMC3292389

21. Schünemann HJ, Dmochowski J, Campbell LA, Grant BJ. A novel approach for quality control of total lung capacity in the clinical pulmonary function laboratory: a study in a veteran population. Respirology. 2003;8(3):365-70. http://dx.doi.org/10.1046/j.1440-1843.2003.00487.x PMid:12911832

22. Spence DP, Kelly YJ, Ahmed J, Calverley PM, Pearson MG. Critical evaluation of computerised $x$ ray planimetry for the measurement of lung volumes. Thorax. 1995;50(4):383-6. http://dx.doi.org/10.1136/thx.50.4.383 PMid:7785011 PMCid:PMC474286

23. Roberts CM, MacRae KD, Seed WA. Multi-breath and single breath helium dilution lung volumes as a test of airway obstruction. Eur Respir J. 1990;3(5):515-20. PMid:2376248

24. Dykstra BJ, Scanlon PD, Kester MM, Beck KC, Enright PL. Lung volumes in 4,774 patients with obstructive lung disease. Chest. 1999;115(1):68-74. http://dx.doi. org/10.1378/chest.115.1.68 PMid:9925064

25. Garcia-Rio F, Dorgham A, Galera R, Casitas R, Martinez E, Alvarez-Sala R, et al. Prediction equations for singlebreath diffusing capacity in subjects aged 65 to 85 years. Chest. 2012;142(1):175-84. http://dx.doi.org/10.1378/ chest.11-2021 PMid:22194584

26. Brugman TM, Morris JF, Temple WP. Comparison of lung volume measurements by single breath helium and multiple breath nitrogen equilibration methods in normal subjects and COPD patients. Respiration. 1986;49(1):52-60. http://dx.doi.org/10.1159/000194859 PMid:3513268

27. Mitchell MM, Renzetti AD Jr. Evaluation of a singlebreath method of measuring total lung capacity. Am Rev Respir Dis. 1968;97(4):571-80. PMid:5644321 


\section{About the authors}

\section{Patricia Chaves Coertjens}

Assistant Professor 11. Federal University of Piauí, Parnaiba, Brazil.

\section{Marli Maria Knorst}

Associate Professor. Federal University of Rio Grande do Sul School of Medicine; and Physician. Department of Pulmonology, Porto Alegre Hospital de Clínicas, Porto Alegre, Brazil.

\section{Anelise Dumke}

Adjunct Professor 1. Department of Physiotherapy, Federal University of the Pampa (southern Rio Grande do Sul), Uruguaiana, Brazil.

\section{Adriane Schmidt Pasqualoto}

Adjunct Professor. Federal University of Santa Maria, Santa Maria, Brazil.

\section{João Riboldi}

Full Professor. Federal University of Rio Grande do Sul, Porto Alegre, Brazil.

\section{Sérgio Saldanha Menna Barreto}

Attending Physician. Porto Alegre Hospital de Clínicas; and Full Professor. Department of Internal Medicine, Federal University of Rio Grande do Sul School of Medicine, Porto Alegre, Brazil. 